Gut, 1974, 25, 858-861

\title{
Hyperphagia in intestinal disease
}

\author{
R. J. C. HALL AND B. CREAMER \\ From St Thomas' Hospital, London
}

SUMMARY Six patients with hyperphagia (ingestion of 5-11000 Kcals/day) associated with severe malabsorption and steatorrhoea are described. The cause of the malabsorption was coeliac disease in three patients, Crohn's disease with ileal resection in two, and carcinoma of the pancreas in one patient. There was no evidence of neurological or endocrine disease (apart from mild diabetes mellitus in the patient with carcinoma of the pancreas) but three patients suffered from severe depression. This association may be commoner than previously realized and be revealed in patients with steatorrhoea of unexplained severity by careful dietary assessment. Its detection has therapeutic implications since restriction of caloric and fat intake decreased steatorrhoea without weight loss in several of the patients described.

Changes in appetite commonly occur in patients with gastrointestinal diseases; anorexia and a low intake are the usual responses even in the face of malabsorption. Gent and Creamer (1968) studied 56 patients with coeliac disease and concluded that weight loss correlated better with anorexia than with the degree of steatorrhoea and found that steatorrhoea was more marked in patients retaining good appetites. Increased appetite is less well known. Dünner, Hirschfeld, and Geraldy (1934) reported a series of patients with idiopathic steatorrhoea and noted that some of these patients had very large appetites and became annoyed if their food intake was limited. Evans and Wollaeger (1966) noted almost invariably increased appetite in patients with malabsorption due to pancreatic disease but no such increase in patients with coeliac disease. The exact extent of this increase was not documented. Increased food intake would seem to be a reasonable compensatory response to weight loss resulting from malabsorption, but the increased intake of the patients presented here grossly exceeds such a premise.

Normal individuals have widely differing appetites, and these differences do not only depend on variations in stature, activity, etc, since individuals comparable in these respects may have very different intakes. The definition of normal or abnormal appetites is therefore difficult. Surveys have suggested that most people in England and Wales eat between 2000 and 3000 Kcals/day (Widdowson, 1936; Thomson, Billewicz, and Passmore, 1961). The Received for publication 24 July 1974.
Department of Health and Social Security recommend (Department of Health and Social Security, 1969) that the ideal food intake for a $65-\mathrm{kg}$ young male manual worker is $3600 \mathrm{Kcals} /$ day and for a $65-\mathrm{kg}$, 75-year-old woman is $1900 \mathrm{Kcals} / \mathrm{day}$.

We present the cases of six patients with severe malabsorption and steatorrhoea in whom food intake was greatly increased and was inappropriate to their circumstances (hyperphagia).

\section{Patients}

The clinical details of the six patients are summarized in the table.

All patients led sedentary lives, lived in the UK, and their premorbid build was not unusually large. A detailed dietary assessment was made by trained dietitians, and hyperphagia was repeatedly found in patients, and observed during hospital admissions. No drugs were being administered although patients 1,2 , and 4 later received oral corticosteroids. Thyroid function was measured in patients 1-5. 131I uptake and serum protein-bound iodine were normal in these patients at the time hyperphagia was noticed.

Calorie intakes ranged from $5000 \mathrm{Kcals} / 24$ hours in patient 3 to $11000 \mathrm{Kcals} / 24$ hours in patient 4 , and fat intakes between $168 \mathrm{~g} / 24$ hours in patient 2 to $556 \mathrm{~g} / 24$ hours in patient 4 . Faecal fat excretion was elevated in patients 3-6 and steatorrhoea was clinically present in patients 1 and 2; despite this faecal loss, the calculated fat absorption was considerable in all patients for whom data were available, and, 


\begin{tabular}{|c|c|c|c|c|c|c|c|c|}
\hline Patient & Age & Sex & Diagnosis & $\begin{array}{l}\text { Observed Duration } \\
\text { of Hyperphagia }\end{array}$ & $\begin{array}{l}\text { Psychiatric } \\
\text { Illness }\end{array}$ & $\begin{array}{l}\text { Maximum Intake } \\
(\text { Kcals } / 24 h)\end{array}$ & $\begin{array}{l}\text { Recorded Fat Intake } \\
(g / 24 h)\end{array}$ & $\begin{array}{l}\text { Faecal Fat Excre- } \\
\text { tion }(g / 24 h)\end{array}$ \\
\hline \multirow[t]{2}{*}{1} & 34 & $\mathbf{F}$ & $\begin{array}{l}\text { Crohn's disease } \\
\text { (R hemicolectomy } \\
+70 \mathrm{~cm} \text { terminal } \\
\text { ileum resected) }\end{array}$ & 1 year & $\begin{array}{l}\text { Mania, on } \\
\text { corticosteroids }\end{array}$ & 8000 & 313 & Not tested \\
\hline & 25 & $\mathbf{F}$ & $\begin{array}{l}\text { Crohn's disease } \\
\text { (R hemicolectomy } \\
+110 \mathrm{~cm} \text { terminal } \\
\text { ileum resected) }\end{array}$ & 2 years & $\begin{array}{l}\text { Severe recurrent } \\
\text { depression }\end{array}$ & 7000 & 168 & Not tested \\
\hline 3 & 53 & $\mathbf{M}$ & $\begin{array}{l}\text { Carcinoma of } \\
\text { pancreas }\end{array}$ & 3 months & - & 5000 & 196 & 80 \\
\hline 4 & 43 & $\mathbf{M}$ & $\begin{array}{l}\text { a Coeliac disease } \\
\text { b Pancreatic atrophy } \\
\text { c Fatty liver }\end{array}$ & 10 years & $\begin{array}{l}\text { Severe chronic } \\
\text { depression }\end{array}$ & 11000 & 556 & 90 \\
\hline $\begin{array}{l}5 \\
6\end{array}$ & $\begin{array}{l}43 \\
32\end{array}$ & $\begin{array}{l}\mathbf{M} \\
\mathbf{M}\end{array}$ & $\begin{array}{l}\text { Coeliac disease } \\
\text { Coeliac disease }\end{array}$ & $\begin{array}{l}8 \text { years } \\
5 \text { years }\end{array}$ & Depression & $\begin{array}{l}9000 \\
7000\end{array}$ & $\begin{array}{l}382 \\
338\end{array}$ & $\begin{array}{l}30 \\
16\end{array}$ \\
\hline
\end{tabular}

Table Summary of clinical details

for example in patient 4 , with faecal fat excretion of $90 \mathrm{~g} / 24$ hours, calculated absorption of dietary fat was $84 \%(460 \mathrm{~g} / 24$ hours $)$. The metabolic fate of this absorbed fat in patients who, despite this, remained underweight is unknown.

Glucose tolerance was assessed in patients 1-5. Patient 3 (carcinoma of the pancreas) had a mildly diabetic test with a two-hour blood sugar of $145 \mathrm{mg} /$ $100 \mathrm{ml}$ after a $50 \mathrm{~g}$ oral glucose load. Cases 1, 2, 4, and 5 received a $100 \mathrm{~g}$ oral load and blood sugar, insulin, and growth hormone levels were followed for three hours; all these patients showed flat blood sugar curves typical of malabsorption. Serum insulin and growth hormone levels were normal in all five patients. Patient 1 had fasting hypoglycaemia (with blood sugar level of $45 \mathrm{mg} \%$ ) at a time when she was no longer hyperphagic. Patient 4 showed late hypoglycaemia, the blood sugar falling to $35 \mathrm{mg} / 100 \mathrm{ml}$ at three hours; this patient had persistently abnormal liver function tests and a liver biopsy specimen contained a great excess of fat. Neither of these patients had symptoms when hypoglycaemia and serum insulin levels were normal.

In patients 2,4 , and 5 reduction of food intake to more normal levels produced an immediate improvement in the steatorrhoea. Patient 4 maintained a constant body weight despite a $40 \%$ reduction in calorie intake (9000 reduced to 5000 $\mathrm{Kcals} /$ day). Patient 5 gained weight on a low-fat diet $(60 \mathrm{~g} /$ day) containing half as many calories (6000 reduced to $2500 \mathrm{Kcals} /$ day), but a small amount of gluten was also eliminated from the diet and this may have been responsible for the weight gain. In patient 1 steatorrhoea diminished and body weight rose during therapy with oral corticosteroids (initially $40 \mathrm{mg}$ prednisone/day, rapidly decreased to $10-15 \mathrm{mg} /$ day over a few weeks and then maintained at this level) and as the patient improved appetite fell to normal levels. Treatment of patient 3 with pancreatin (10 $\mathrm{g}$ tds) resulted in a dramatic decrease in steatorrhoea, faecal fat excretion falling from 88 $\mathrm{g} /$ day to $20 \mathrm{~g}$ /day, while his food intake immediately fell from 5000 to $2000 \mathrm{Kcals} /$ day. Despite this diminished appetite his body weight rose by $8 \mathrm{~kg}$ in two months.

None of the patients have shown evidence of neurological disease, although several have had prolonged psychiatric disturbances (see table).

\section{Case History}

A 43-year-old aircraft fitter presented in 1965 with weight loss, excessive hunger, and intermittent abdominal bloating of recent onset; he had suffered occasional bouts of pale frothy diarrhoea since childhood. He was small and thin (height $5 \mathrm{ft} 4 \mathrm{in}$, weight $41.5 \mathrm{~kg}$ ), but had no other abnormal signs. Investigation showed deficiencies of iron, folic acid, and vitamin $\mathrm{B}_{12}$; the jejunal biopsy specim?n revealed total villous atrophy and the radiological appearances of the small bowel were typical of coeliac disease. Faecal fat excretion was $22 \mathrm{~g} / 24$ hours. Dietary assessment revealed that he was eating $9000 \mathrm{Kcals} /$ day.

A gluten-free diet resulted in a $6 \mathrm{~kg}$ weight gain in six months and his general health improved but the diarrhoea persisted and he continued to eat 6000 Kcals/day. Trial of a smaller but normal food intake $(2500 \mathrm{Kcals} /$ day $)$ resulted in an immediate fall in stool frequency from eight/day to two/day without loss of weight. His food intake at home soon rose to $6000 \mathrm{Kcals} /$ day again and over the next six years his dietary intake remained at this level; he had mild but persistent diarrhoea and his weight remained steady. In 1972 the diarrhoea worsened, and his weight began to fall. He had always followed his gluten-free diet obsessionally, but on this occasion he had been unwittingly infringing it. Repeat jejunal 
biopsy showed that there was still total villous atrophy and faecal fat excretion was $32 \mathrm{~g} /$ day. A period of three weeks in hospital on a strict glutenfree diet did not improve the steatorrhoea but restriction of dietary fat to $60 \mathrm{~g} /$ day and calories to $2500 \mathrm{Kcals} /$ day produced an immediate fall in the frequency of stools to two a day. In the next month he gained $3 \mathrm{~kg}$ in weight on a low-fat, gluten-free diet.

\section{Discussion}

Both man and animals maintain remarkably constant body weights over long periods of time (Anand, 1967) and appropriate food intake is one important factor in this control. Animal experiments suggest that control of food intake is exerted by hypothalamic centres (Brooks, Lambert, and Bard, 1942; Mayer, French, Zighera, and Barrnett, 1955 ) and that the activity of these centres may be modified by stimuli from many sources, including the gastrointestinal tract (Sharma, Anand, Dua, and Singh, 1961), blood levels of glucose, glucose arteriovenous differences (Anand, Chhina, Sharma, Dua, and Singh, 1964), and temperature changes (Brobeck and Yale, 1948). Hypothalamic tumours in man (Bauer, 1954; Reeves and Plum, 1969) may sometimes result in hyperphagia or anorexia and these may be associated with disturbances of thirst and temperature control. Other neurological disease and also many psychiatric disorders may be associated with hyperphagia (Bauer, 1954; Critchley, 1962; Reeves and Plum, 1969).

The six patients described here suffered from severe malabsorption and steatorrhoea. The responses to dietary alteration and treatment of malabsorption suggest that there may be some relationship between hyperphagia and steatorrhoea in these patients. Normal individuals may have increased faecal fat excretion (Wollaeger, Comfort, and Osterberg, 1947; Kasper, 1970), although not invariably (Annegers, Boutwell, and Ivy, 1948), when fed high-fat diets which in some cases (Kasper, 1970) were comparable to the highest fat intakes of these patients. Hyperphagia may be occurring in an attempt to compensate for malabsorption, but the increased dietary intake, in particular of fat, may result in no absorptive gain or even a nett loss of absorption and in either case severe diarrhoea. The presence in the bowel of excess dietary hydroxy fatty acids, which have been shown to inhibit intestinal water absorption (Phillips, 1972), might lead to intestinal hurry and decreased absorption of nutrients. Patients with malabsorption caused by small bowel resection showed improved nutrition when dietary fat is restricted (Booth, 1961); the patients described here seem to respond in a similar way to restriction of fat intake. Both the patients described here with Crohn's disease had had extensive ileal resections. The high calculated fat absorption makes the improvement in nutrition resulting from dietary fat limitation difficult to explain unless diminished intestinal hurry leads to greatly improved absorption of other nutrients.

Hypoglycaemia cannot be dismissed as a possible aetiological factor in patient 4 although serum insulin values were normal. Fasting hypoglycaemia in patient 1 is of unknown aetiology and significance since it was observed at a time when the patient was no longer hyperphagic and was not associated with feelings of hunger. The mild diabetes in patient 3 was still present and untreated after hyperphagia had ceased following treatment with pancreatin and was therefore probably not significant.

Psychiatric illness, including depression, may result in hyperphagia (Critchley, 1962), and three of the patients described suffered severe depressive illnesses which in two cases required electroconvulsive therapy. Psychiatric abnormality may be an important aetiological factor in these patients.

The association of increased appetite with malabsorption and steatorrhoea may be more prevalent than commonly realized, since in four of our patients it only came to light when the patients commented on the cost of buying sufficient food to satisfy their hunger, or when dietary assessment was carried out in an attempt to explain gross, intractable steatorrhoea. Hyperphagia may also lead to diagnostic confusion; patient 3 presented with complaints of excessive hunger and weight loss and no mention of diarrhoea. This led to his initial referral for the investigation of suspected thyrotoxicosis.

Hyperphagia and malabsorption may be causally related in these patients or other factors, in particular psychiatric disorder, may be causing hyperphagia. Whatever its basis this association is worth considering when patients have severe steatorrhoea which does not respond to treatment. Only a few patients complain of excessive appetite (two of the present series) and a dietary assessment of patients with steatorrhoea is usually necessary to reveal this phenomenon. If hyperphagia is found patients may derive benefit in the form of decreased diarrhoea without weight loss from dietary restriction, in particular of fat, to normal or low levels.

\section{R eferences}

Anand, B. K. (1967). In Handbook of Physiology, Sect. 6, Alimentary Canal edited by C. F. Code, Vol. 1, p. 260. American Physiological Society, Washington, D.C.

Anand, B. K., Chhina, G. S., Sharma, K. N., Dua, S., and Singh, B. (1964). Activity of single neurons in the hypothalamic feeding centers: effect of glucose. Amer. J. Physiol., 207, 1146-1154. 
Annegers, J. H., Boutwell, J. H., and Ivy, A. C. (1948). The effect of dietary fat on fecal fat excretion and subjective symptoms in man. Gastroenterology, 10, 486-495.

Bauer, H. G. (1954). Endocrine and other clinical manifestations of hypothalamic disease. J. clin. Endocr., 14, 13-31.

Booth, C. C. (1961). The metabolic effects of intestinal resection in man. Postgrad. med. J., 37, 725-739.

Brobeck, J. R. (1948). Food intake as a mechanism of temperature regulation. Yale J. Biol. Med., 20, 545-552.

Brooks, C. McC., Lambert, E. F., and Bard, P. (1942). Experimental production of obesity in the monkey (Macaca mulatta). Fed. Proc., 1, 11.

Critchley, M. (1962). Periodic hypersomnia and megaphagia in adolescent males. Brain, 85, 627-656.

Department of Health and Social Security (1969). Recommended intakes of nutrients for the United Kingdom. Rep. Publ. Hlth Med. Subj., No. 120, HMSO, London.

Dünner, L., Hirschfeld, H., and Geraldy, M. (1934). Zur Pathogenese und Klinik der Nichttropischen Sprue. (Fethresorptionskrankheit). Klin. Wschr., 1, 138-141.

Evans, W. B., and Wollaeger, E. D. (1966). Incidence and severity of nutritional deficiency states in chronic exocrine pancreatic insufficiency: comparison with non-tropical sprue. Amer. J. dig. Dis., 11, 594-606.

Gent, A. E., and Creamer, B. (1968). Faecal fats, appetite and weight loss in the coeliac syndrome. Lancet, 1, 1063-1064.
Kasper, H. (1970). Faecal fat excretion, diarrhea and subjective complaints with highly dosed oral fat intake. Digestion, 3, 312330.

Mayer, J., French, R. G., Zighera, C. F., and Barrnett, R. J. (1955). Hypothalamic obesity in the mouse: production, description. and metabolic characteristics. Amer. J. Physiol., 182, 75-82.

Phillips, S. F. (1972). Diarrhea: a current view of the pathophysiology Gastroenterology, 63, 495-518.

Reeves, A. G., and Plum, F. (1969). Hyperphagia, rage and dementia accompanying a ventromedial hypothalamic neoplasm. Arch. Neurol., 20, 616-624.

Sharma, K. N., Anand, B. K., Dua, S., and Singh, B. (1961). Role of stomach in regulation of activities of hypothalamic feeding centers. Amer. J. Physiol., 201, 593-598.

Thomson, A. M., Billewicz, W. Z., and Passmore, R. (1961). The relation between calorie intake and body-weight in man. Lancet. 1, 1027-1028.

Widdowson, E. M. (1936). A study of English diets by the individual method. J. Hyg. (Lond.), 36, 269-292.

Wollaeger, E. E., Comfort, M. W., and Osterberg, A. E. (1947). Total solids, fats and nitrogen in the feces: III. A study of normal persons taking a test diet containing a moderate amount of fat; comparison with results obtained with normal persons taking a test diet containing a large amount of fat. Gastroenterology, 9, 272-283. 